\title{
Temporal changes in the dominance of major planktonic bacterial groups in an alpine lake: discrepancy with their contribution to bacterial production
}

\author{
María Teresa Pérez*, Ruben Sommaruga \\ Laboratory of Aquatic Photobiology and Plankton Ecology, Institute of Ecology, University of Innsbruck, 6020 Innsbruck, \\ Austria
}

\begin{abstract}
We tested the idea that temporal changes in the numerical dominance of major bacterial groups are not necessarily coupled to those in bacterial production. The seasonal dynamics of the bacterial community in the water column of an alpine lake were followed from late spring until the autumn at either bi-weekly or monthly intervals. Changes in community structure were tracked by fluorescence in situ hybridization combined with catalyzed reporter deposition (CARD-FISH); the contribution of the dominant bacterial groups to leucine incorporation was assessed by microautoradiography (MAR). Before ice-out, the bacterial assemblage was dominated by Actinobacteria. Immediately afterwards, their relative abundance, and that of Cytophaga-like bacteria, increased in the water column, suggesting that they had taken advantage of the input of dissolved organic matter (DOM) during the melting of the ice. During summer, Betaproteobacteria and Actinobacteria together accounted for $>50 \%$ of the cell counts; however, their maxima were separated temporally and vertically. Water temperature, DOM, and grazing influenced their antagonistic behavior. Alphaproteobacteria were consistently present, although their abundance was generally low. Regardless of their relative abundance, Betaproteobacteria dominated the assemblage of leucine-positive cells, and the relative abundance of their R-BT subgroup closely matched that of active Betaproteobacteria. Of the cells positive for leucine incorporation, the contribution of Actinobacteria was lower than expected from their relative abundance. Our results show that bacterial abundance and production are not necessarily dominated by the same phylogenetic groups.
\end{abstract}

KEY WORDS: Seasonality $\cdot$ Leucine incorporation $\cdot$ MAR-FISH $\cdot$ Actinobacteria $\cdot$ Betaproteobacteria

\section{INTRODUCTION}

How the microbial community structure relates to ecosystem functioning is one of the major challenges of ecological research (Loreau et al. 2001). In the last decade, several protocols (Lee et al. 1999, Ouverney \& Fuhrman 1999, Cottrell \& Kirchman 2000) that combine fluorescence in situ hybridization (FISH) with microautoradiography (MAR) have made it possible to relate in situ taxonomic identification (Amann et al. 1995) to single-cell activity, thus bridging the gap between bacterial community structure and function
(Ouverney \& Furhman 1999). Bacterial utilization of dissolved organic matter (DOM) and the subsequent production of bacterial biomass are crucial steps in the biogeochemical carbon cycle. Nevertheless, the contribution of major phylogenetic groups to total bacterial biomass production has been studied in few ecosystems (Cottrell \& Kirchman 2003, Hornák et al. 2006, Zhang et al. 2006). The results of these studies point to a preponderant contribution of Betaproteobacteria to bacterial production in freshwater habitats. However, none of these reports included the abundant freshwater group Actinobacteria (Glöckner et al. 2000, War- 
necke et al. 2005). Yet, some studies analyzing the contribution of the Actinobacteria to leucine incorporation have shown that it was proportional to their representation in the community structure (Pérez et al. 2010), whereas others did not provide such information (Buck et al. 2009, Hornák et al. 2010). Furthermore, the activity of different bacterial groups has been shown to change over time as a consequence, for example, of resource fluctuations (Alonso-Sáez \& Gasol 2007, Hornák et al. 2010) or seasonal changes in other environmental parameters (Salcher et al. 2010).

Alpine lakes (i.e. those situated above the tree-line) are extreme environments subject to strong seasonal changes in nutrient availability, temperature, and light conditions between the ice-covered and the ice-free seasons (Sommaruga 2001). The ice-covered season lasts typically for 7 to 9 mo each year. The ice-out is followed by a spring overturn (June) and a distinct thermal stratification until the autumn overturn (Pechlaner 1971). These fluctuations are considered as key factors for understanding the dynamics of the plankton community in these lakes. Thus, it is important to assess whether the contribution of the main freshwater groups to bacterial production is always proportional to their relative abundance-despite the strong seasonal patterns in both bacterial abundance and production rates (Wille et al. 1999).

Here, we present the results of a study of an alpine lake where we followed, in detail, the seasonal dynamics of the bacterioplankton in the water column. Previous seasonal studies did not include all relevant groups (Pernthaler et al. 1998) or were conducted at a single depth (Glöckner et al. 2000). Concomitantly, we followed the contribution of the dominant bacterial groups to leucine incorporation using MAR-FISH to test whether changes in their relative contribution to bacterial production were coupled to changes in their abundance.

\section{MATERIALS AND METHODS}

Study site and sampling procedure. Gossenköllesee (GKS) is a small lake (area: $0.017 \mathrm{~km}^{2}$ ) located at $2417 \mathrm{~m}$ above sea level in the Austrian Central Alps $\left(47^{\circ} 13^{\prime} \mathrm{N}, 11^{\circ} 01^{\prime} \mathrm{E}\right)$. GKS is a dimictic and holomictic lake, with a maximum depth of $9.9 \mathrm{~m}$. Its catchment area is composed of crystalline bedrock covered with a layer of poor soil and sparse patches of alpine rankers. The lake is usually covered by ice for 6 to 7 mo each year. Background information on DOM dynamics, chemical composition and other variables can be found elsewhere (Sommaruga \& Augustin 2006).

Sampling started in late spring (20 May 2005), when the lake was still ice-covered, and ended in the late autumn (9 November 2005), shortly before the lake froze. Sampling was done from a boat in the middle of the lake at bi-weekly or monthly intervals. Water samples were collected at 5 different depths (every $2 \mathrm{~m}$, from the surface to a depth of $8 \mathrm{~m}$ ) with a $5 \mathrm{l}$ Schindler-Patalas sampler equipped with a thermometer. During the ice-covered period, water samples were collected through a hole opened in the ice cover in the central area of the lake. Before ice-out, samples for assessing bacterial composition and single-cell activity were collected only at depths of 2 and $4 \mathrm{~m}$. On every sampling date, we collected single samples for chlorophyll a (chl a), dissolved organic carbon (DOC), total dissolved nitrogen (TDN) and inorganic nutrients. Triplicate water samples were used for bacterial abundance, and duplicates (plus a negative control) were used for leucine bulk incorporation rates. Single samples for MAR-FISH were incubated for $1 \mathrm{~h}$, immediately after collection, at in situ temperature with $\mathrm{L}-\left[{ }^{3} \mathrm{H}\right]$ leucine (specific activity: $65 \mathrm{Ci} \mathrm{mmol}^{-1}$; $20 \mathrm{nmol} \mathrm{l}^{-1}$ final conc.). The incubation was stopped by adding formaldehyde at a final concentration of $2 \%$. Samples were left at $4{ }^{\circ} \mathrm{C}$ overnight; on the next day they were filtered onto white polycarbonate filters (Millipore, GTTP). The filters were stored at $-20^{\circ} \mathrm{C}$ until further processing.

Chlorophyll a. For chl a analysis, 2 l of lake water were filtered onto Whatman GF/F filters at low vacuum pressure. Filters were then stored frozen until extraction (within $4 \mathrm{mo}$ ). Extraction and chl a determination were done as described in Tartarotti \& Sommaruga (2006). The equation of Lorenzen (1967) was used to calculate the concentration of chl $a$.

DOC and TDN concentrations. Immediately after sampling, sub-samples for DOC and TDN analysis were filtered through a precombusted $\left(4 \mathrm{~h}\right.$ at $\left.450^{\circ} \mathrm{C}\right)$ GF/F filter (Whatman) placed on a stainless steel syringe holder. Filters were rinsed first with Milli-Q water and then with the sample. The filtrate was collected in combusted glass bottles (Schott), acidified with $\mathrm{HCl}$ to $\mathrm{pH} 2$, and stored in the dark at $4{ }^{\circ} \mathrm{C}$ until further analysis (within $48 \mathrm{~h}$ ). DOC and TDN concentrations were measured with a total organic carbon analyzer (Shimadzu TOC-Vc series) equipped with a TNM-1 module. Both parameters were detected simultaneously after combustion and catalytic oxidation of the injected sample.

Analysis of nutrients. Nitrate concentration $\left(\mathrm{NO}_{3}{ }^{-}\right.$ $\mathrm{N}$, mg $\mathrm{l}^{-1}$ ) was assessed using spectrophotometry after reduction with sodium salicylate and Seignette salt, as described by Taras (1971). Total dissolved phosphorus (TDP) was determined with a spectrophotometer using the molybdate blue method after digestion with sulphuric acid and hydrogen peroxide (Schmid \& Ambühl 1965). 
Bulk bacterial production. Leucine bulk incorporation rates were measured in duplicate samples and in a formaldehyde-killed control. Samples (5 to $10 \mathrm{ml}$ ) were incubated with $20 \mathrm{nmol} \mathrm{l}^{-1}$ (final conc.) of $\mathrm{L}-\left[{ }^{3} \mathrm{H}\right]$ leucine (of the same specific activity as that used for microautoradiography) at in situ temperature in the dark for $1 \mathrm{~h}$; the incubations were terminated by adding formaldehyde ( $2 \%$ final conc.). Subsequently, the samples were filtered through Millipore GTTP filters (pore size $0.22 \mu \mathrm{m}$ ) and rinsed twice with $5 \mathrm{ml}$ of $5 \%$ trichloroacetic acid (TCA) for $5 \mathrm{~min}$. The filters were dissolved in $5 \mathrm{ml}$ of scintillation cocktail (Ready safe, Beckman-Coulter) and the radioactivity of the filters assessed after $15 \mathrm{~h}$.

Bacterial abundance. Triplicate samples $(10 \mathrm{ml})$, fixed with formaldehyde ( $2 \%$ final conc.), were stained with 4',6-diamidino-2-phenylindole (DAPI, $1 \mu \mathrm{g} \mathrm{ml}{ }^{-1}$ final conc.) and filtered onto black polycarbonate membranes (Millipore, GTBP, $0.22 \mu \mathrm{m}$ ). Bacterial abundance was determined by epifluorescence microscopy. At least 400 cells per filter were counted.

Hybridization and tyramide signal amplification. FISH with horseradish peroxidase-labeled probes was done on filter sections according to Pernthaler et al. (2002), using a modified permeabilization protocol for freshwater bacteria (Sekar et al. 2003). We used oligonucleotide probes (ThermoHybaid) targeting the domain Bacteria (EUB I-III; Daims et al. 1999), Alphaproteobacteria (ALF968; Neef 1997), Betaproteobacteria (BET42a; Manz et al. 1992) and its subgroup R-BT (RBT065; Šimek et al. 2001), Cytophaga-like bacteria within the phylum Bacteroidetes (CF319a; Manz et al. 1996), and Actinobacteria (HGC69a; Roller et al. 1994). The formamide concentration in the hybridization buffer was always 55\%, except for probe HGC69a (35\%). To quantify Archaea, FISH was performed with the Cy3labeled probe ARCH915 as previously described (Glöckner et al. 1996, Pernthaler et al. 1998). In total, 300 individual preparations were analyzed as described in the following section.

Microautoradiography. Samples were subjected to MAR as described by Tabor \& Neihof (1982) after the hybridization step. Briefly, cells were transferred from filters to glass coverslips (Cottrell \& Kirchman 2000, 2003) using $0.2 \%$ gelatin for improved transfer efficiency ( $\sim 90 \%$ of cells). Glass slides, with coverslips attached, were coated with a molten Kodak NTB autoradiography emulsion diluted 2:1 with distilled water. Slides were placed on an ice-cold aluminum block for $5 \mathrm{~min}$, to harden the emulsion, before being transferred to light-tight boxes for exposure at $4{ }^{\circ} \mathrm{C}$. Different times $(24,48,72$ and $96 \mathrm{~h})$ were tested to determine the optimum exposure time for maximizing the detection of labeled cells. Samples collected under the ice cover were exposed for $72 \mathrm{~h}$, whereas the rest of the samples were exposed for $48 \mathrm{~h}$. Development and fixation were done according to the specifications of the manufacturer (Kodak). Afterwards, cells were stained with an anti-fading solution containing DAPI (final conc.: $1 \mu \mathrm{g} \mathrm{ml}^{-1}$ ), and the slides were examined with a Zeiss Axioplan microscope equipped with a 100 W Hg lamp. Silver grains around bacterial cells were observed using the transmission mode of the instrument. Cells were counted in at least 20 randomly selected fields and, for every field, 4 different counts were recorded: (1) DAPI+ cells; (2) probe-specific-positive cells; (3) DAPI+, MAR+ cells; and (4) probe-specific and MAR+ cells. Routinely, at least 350 DAPIstained cells were counted per sample, or 1000 DAPI-stained cells when the calculated relative abundance was $<1 \%$.

Data analysis. Spearman rank correlation coefficients were calculated (whole data set $n=44$ ) to relate changes in bacterial community composition and activity to environmental parameters. Spearman rank correlation coefficients (whole data set $n=44$ ) were calculated to relate changes in bacterial community composition and activity to environmental parameters. For that purpose, we used the relative abundance of different bacterial groups expressed as percentage and the physico-chemical variables measured. Attempts to normalize some of these variables proved unsuccessful. Statistical analyses were done using SigmaStat (Systat Software).

\section{RESULTS}

\section{Environmental conditions and bulk bacterial production}

Data on the changes in water temperature, chl a concentration, DOC, TDN and bulk bacterial production (Fig. 1) were used to define periods when important physical and biological processes had taken place in the lake. Accordingly, we selected the following 5 dates to look in detail at the composition of the bacterial community and at leucine incorporation by the dominant bacterial groups:

(1) 14 June 2005, representing the situation before ice-out, characterized by low water temperature and relatively high concentrations of DOC and TDN (Fig. 1B,D); (2) 29 June 2005, after the spring overturn, which led to an increase in concentrations of TDN and bacterial production; (3) 28 July 2005, corresponding to the maximum of bacterial production, high water temperature, and high concentrations of DOC at the surface, as well as high values of chl a at the bottom; (4) 9 August 2005, deep chlorophyll maximum; (5) 12 October 2005, after the autumn overturn, when water 

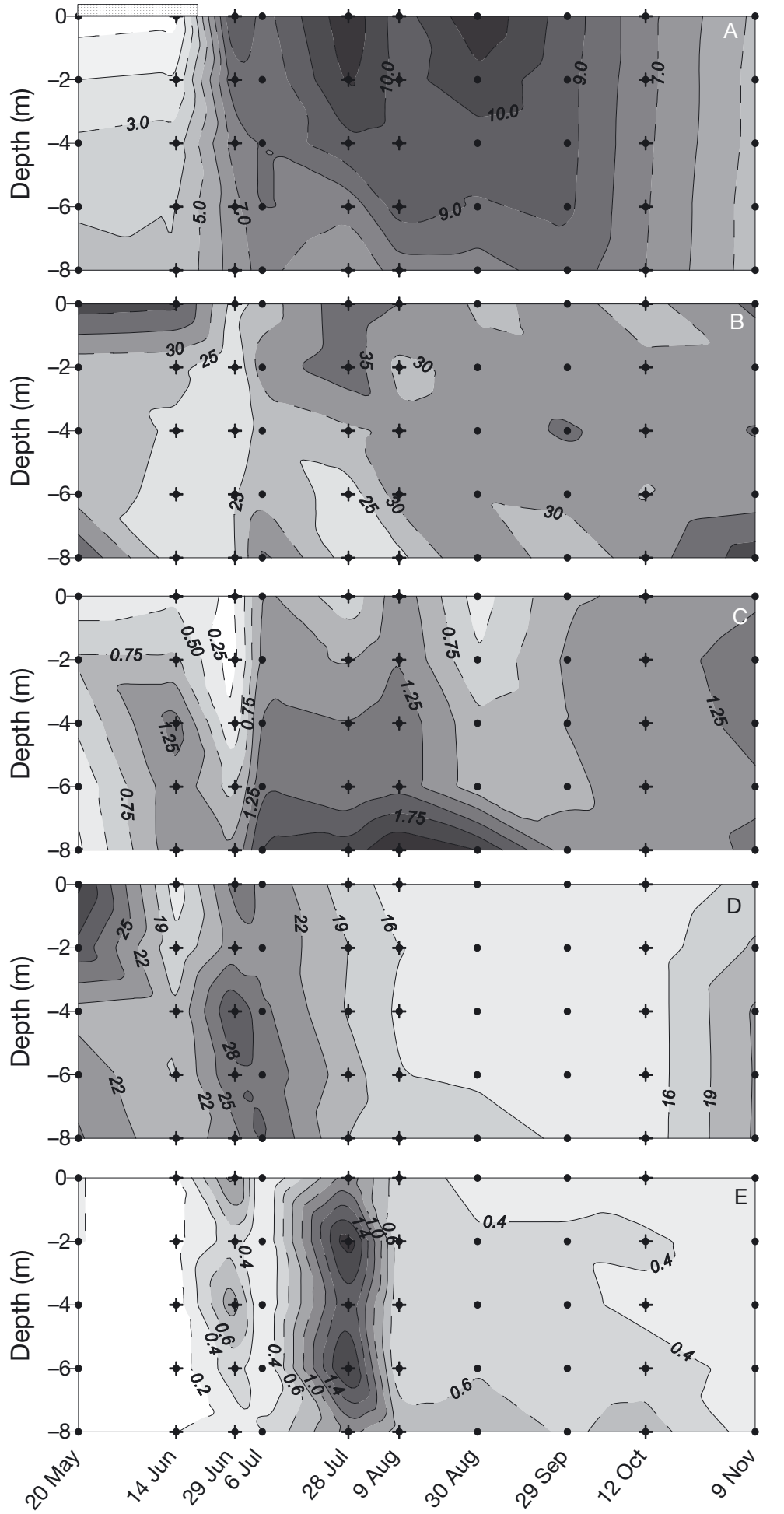

Fig. 1. Temporal and vertical fluctuations in $(\mathrm{A})$ temperature $\left({ }^{\circ} \mathrm{C}\right)$, (B) dissolved organic carbon $(\mu \mathrm{M}),(\mathrm{C})$ chlorophyll a concentration $\left(\mu \mathrm{g} \mathrm{l}^{-1}\right)$, (D) total dissolved nitrogen $(\mu \mathrm{M})$, and $(\mathrm{E})$ bacterial production (nmol Leu $\mathrm{l}^{-1}$ $\mathrm{d}^{-1}$ ) in the Gossenköllesee (GKS) during the study period in 2005. The grey box above Panel A represents ice cover. Crosses indicate the dates chosen for a more detailed analysis of the bacterial community structure and leucine incorporation at the single-cell level. Dots show time and depth of the measured data set temperature, and concentrations of TDN, chl $a$ and DOC were homogeneous in the water column (Fig. 1).

\section{Bacterial abundance and community structure}

Hybridization efficiency varied during the seasonal cycle. The lowest detection rate of probe EUBI-III ( $62 \%$ of DAPI counts) corresponded to samples collected under ice, and the highest detection rate corresponded to those samples taken immediately after the spring overturn (86 to $90 \%$ of DAPI counts). The group-specific probes that we used covered $>60 \%$ of the domain Bacteria in the ice-covered period and $~ 91 \%$ during the ice-free season (range 74 to $100 \%$ ). Probe ARC915 detected generally $<1 \%$ of DAPI-stained cells, except for the samples from October and November, when Archaea accounted for 2 to $6 \%$ of DAPI-stained cells (data not shown).

The ice-covered period (Fig. 2A) was characterized by low bacterial abundances, ranging from 1.2 to $1.4 \times 10^{5}$ cells $\mathrm{ml}^{-1}$, and the dominance of Actinobacteria ( 20 to $30 \%$ of DAPI counts). After the spring overturn, bacterial abundance doubled in the whole water column (Fig. 2B), and the relative abundance of Actinobacteria increased to $50 \%$ of DAPI counts at $6 \mathrm{~m}$ depth. Further, the relative abundance of Cytophagalike bacteria also increased, representing $\sim 22 \%$ of DAPI counts throughout the water column. The relative abundance of Betaproteobacteria remained low $(\sim 10 \%$ of DAPI counts).

On 28 July, bacterial abundance increased only below $6 \mathrm{~m}$ depth (Fig. 2C). Betaproteobacteria dominated the bacterial community at the surface, whereas Actinobacteria did so at $4 \mathrm{~m}$ and in deeper layers of water. The contribution of the R-BT subgroup to Betaproteobacteria was $\sim 72 \%$ in the upper water layers and ranged from 87 to $96 \%$ below $4 \mathrm{~m}$ depth. The relative abundance of Cytophaga-like bacteria increased slightly with depth from $7 \%$ of DAPI counts at $0 \mathrm{~m}$ to $12 \%$ of DAPI counts at $8 \mathrm{~m}$ depth.

On 9 August (Fig. 2D), bacterial abundance peaked. Betaproteobacteria was the most abundant bacterial group ( $30 \%$ of DAPI counts), with high absolute abundances in the 


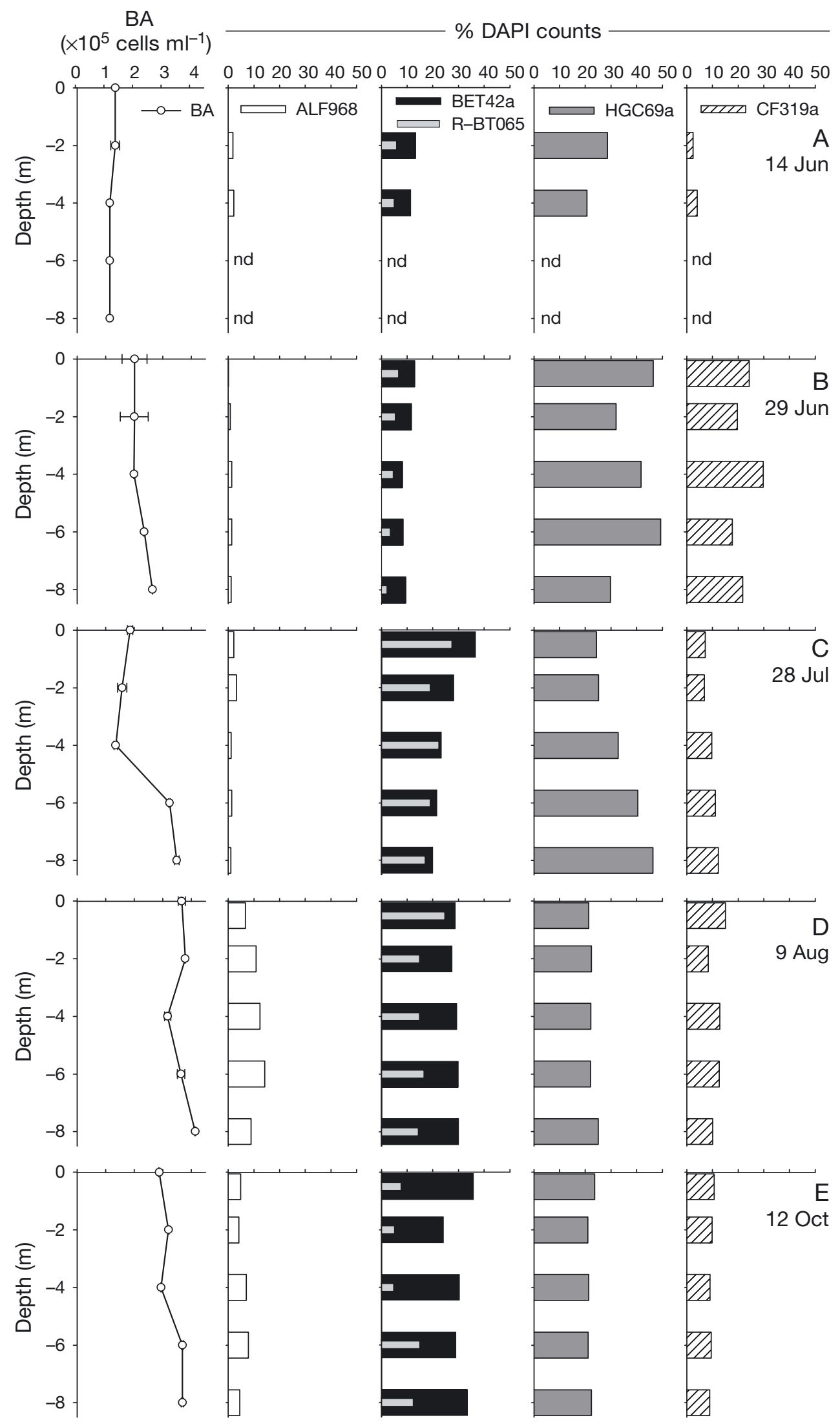

Fig. 2. Vertical distribution of bacterial abundance (BA) and bacteria targeted by probes ALF968 (Alphaproteobacteria), BET42a (Betaproteobacteria), R-BT065 (R-BT subgroup of Betaproteobacteria), HGC69a (Actinobacteria), and CF319a (Cytophaga-like bacteria) in the Gossenköllesee (GKS) during the most relevant events of the seasonal cycle. On 14 June 2005, the bacterial community structure was assessed only at 2 and $4 \mathrm{~m}$ depths. nd: no data. DAPI: 4', 6-diamidino-2-phenylindole 
water column ranging from 0.9 to $1.1 \times 10^{5}$ cells $\mathrm{ml}^{-1}$. The contribution of the R-BT subgroup decreased with depth and represented $86 \%$ of Betaproteobacteria at the surface, but only $48 \%$ at $8 \mathrm{~m}$ depth. The relative abundance of Alphaproteobacteria reached its maximum at $6 \mathrm{~m}$ depth (14\% of DAPI counts).

After the autumn overturn (12 October, Fig. 2E), bac-

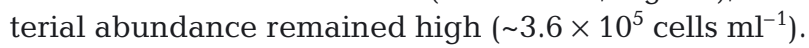
Betaproteobacteria still dominated the bacterial assemblage, in terms of both relative and absolute abundance, but the R-BT subgroup comprised $<30 \%$ of Betaproteobacteria. The relative abundance of Actinobacteria and Cytophaga-like bacteria was rather constant throughout the water column.

\section{Seasonal dynamics in single-cell activity}

In general, Betaproteobacteria and Actinobacteria accounted for $>50 \%$ of all cells with visible leucine incorporation detected by MAR, and sometimes they even comprised all of the leucine-positive cells, particularly in the epilimnion (the upper $4 \mathrm{~m}$ ). Betaproteobacteria represented between 25 and $72 \%$ of leucine-positive bacteria, whereas the contribution of Actinobacteria showed a 7 -fold variation, ranging from 7 to $48 \%$ of leucine-positive cells (Fig. 3). The contribution of Betaproteobacteria to leucine incorporation was always higher than expected from their relative abundance, whereas that of the Actinobacteria was either lower or equivalent to their numerical contribution to the community structure (Fig. 3).

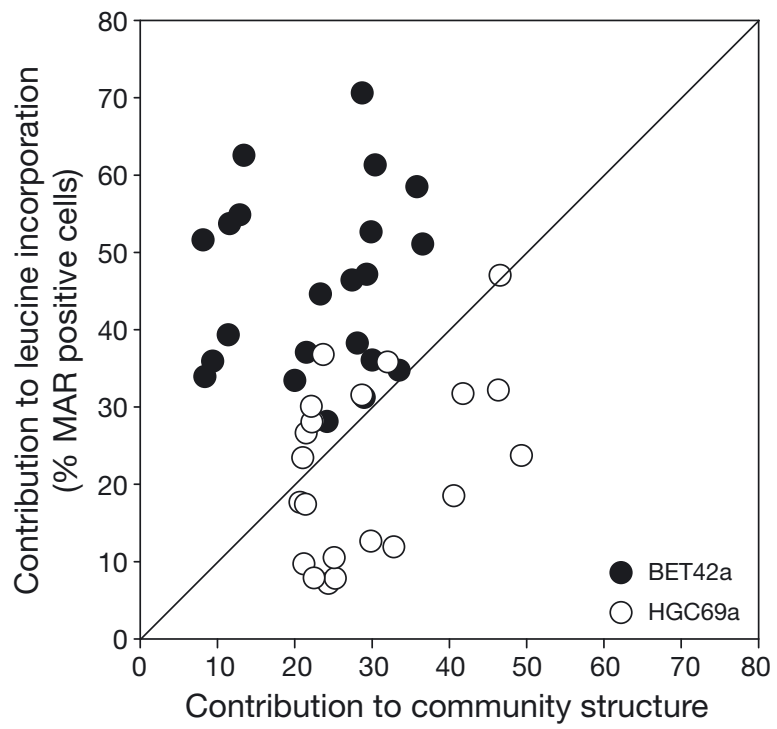

(\% DAPI counts)

Fig. 3. Relative contribution of the dominant bacterial groups to leucine incorporation versus community structure. BET42a: Betaproteobacteria; HGC69a: Actinobacteria. The diagonal line represents a 1:1 relationship. MAR: microautoradiography

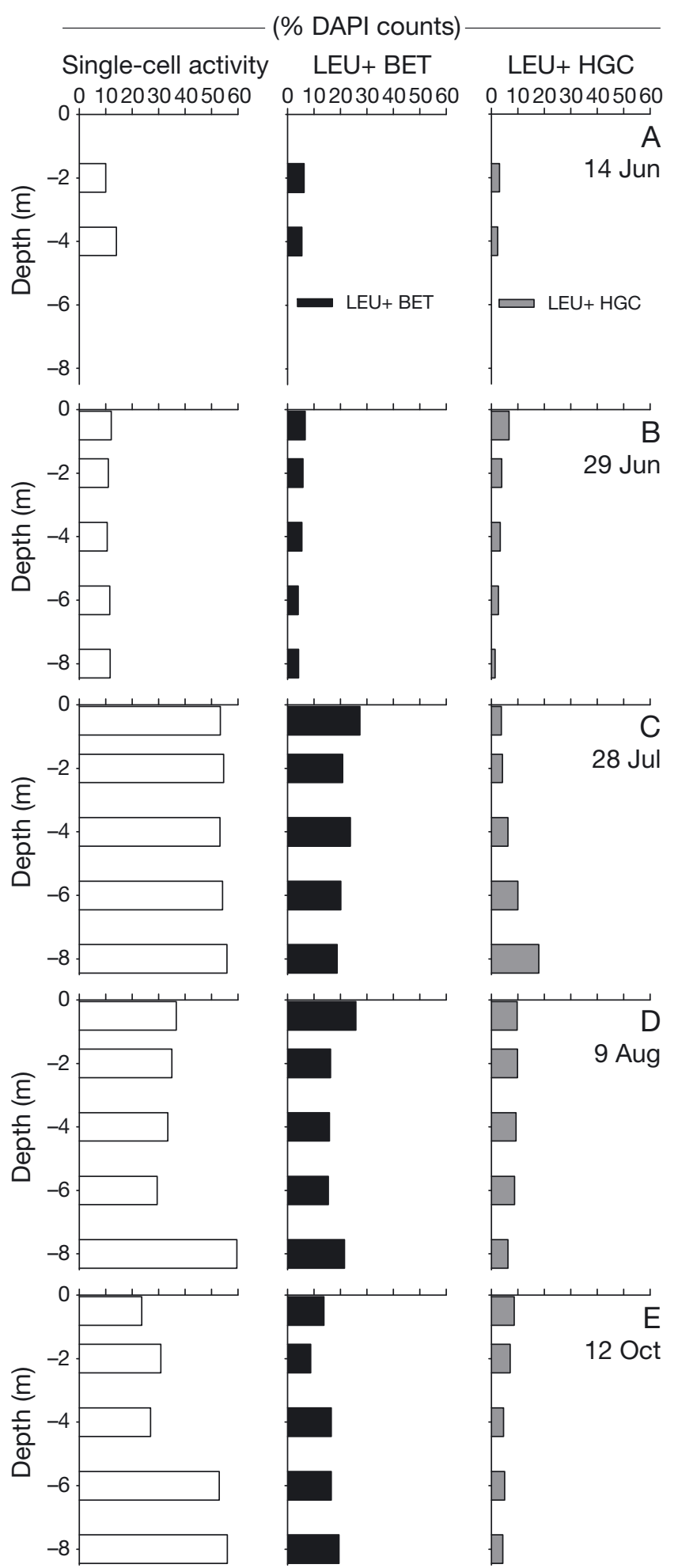

Fig. 4. Vertical distribution of the single-cell activity (total leucine-positive bacteria), and leucine-positive Betaproteobacteria (LEU+ BET) and leucine-positive Actinobacteria (LEU+ HGC) in the Gossenköllesee (GKS) during the most relevant events of the seasonal cycle. On 14 June 2005, samples were taken only at 2 and $4 \mathrm{~m}$ depths. DAPI: 4', 6-diamidino-2-phenylindole 
The relative abundance of leucine-incorporating cells under ice was low (on average $~ 11 \%$ of DAPI counts), and most of them were Betaproteobacteria (Fig. 4A). Unlike bulk bacterial production rates, the relative abundance of leucine-positive cells did not increase after the spring overturn (Fig. 4B). In this vertical profile, Actinobacteria represented $\sim 50 \%$ of the cells incorporating leucine at $0 \mathrm{~m}$, but at any other depth the Betaproteobacteria dominated the assemblage of MAR+ cells (Fig. 4B). In July, leucine-incorporating cells represented $\sim 50 \%$ of DAPI counts throughout the water column (Fig. $4 \mathrm{C}$ ). The relative abundance of leucine-positive cells increased for both groups, but showed different trends. The contribution of Actinobacteria to leucine incorporation increased with depth, whereas that of the Betaproteobacteria slightly decreased. In August, the abundance of leucine-positive cells decreased at every depth, except at $8 \mathrm{~m}$, where $\sim 58 \%$ of DAPI-stained cells showed leucine incorporation (Fig. 4D). Leucine-positive Betaproteobacteria contributed on average to $17 \%$ of DAPI counts, except for depths of 0 and $8 \mathrm{~m}$, where they represented $>22 \%$ DAPI counts. Active Actinobacteria were less numerous, and their contribution to leucine incorporation decreased with depth. After the autumn overturn, activity decreased in the upper $4 \mathrm{~m}$ of the water column, but it was $>40 \%$ of DAPI counts below this depth (Fig. 4E).

\section{Relationships between the dominant bacterial groups and environmental variables}

Betaproteobacteria, and particularly its R-BT subgroup (Table 1), showed significant positive relation-

Table 1. Spearman rank correlation coefficients between the relative abundance (\% DAPI counts) of Alphaproteobacteria (ALF), Betaproteobacteria (BET) and its R-BT subgroup (RBT), Actinobacteria (HGC), and Cytophaga-like bacteria $(\mathrm{CF})$, and different bacterial and environmental parameters. BP: bulk bacterial production; Activity: relative abundance of leucine-incorporating cells; Temp: water temperature; Chl a: chlorophyll $a_{\text {; }}$ DOC: dissolved organic carbon; TDN: total dissolved nitrogen; TDP: total dissolved phosphorus; ns: not significant. ${ }^{*} \mathrm{p}<0.05 ;{ }^{* *} \mathrm{p}<0.01 ;{ }^{* * *} \mathrm{p}<0.001$

\begin{tabular}{|lccccc|}
\hline & ALF & BET & R-BT & HGC & CF \\
\hline BP & ns & $0.37^{*}$ & $0.52^{* *}$ & ns & $0.69^{* * *}$ \\
Activity & ns & $0.51^{* *}$ & $0.65^{* * *}$ & ns & ns \\
Temp & ns & ns & $0.56^{* * *}$ & ns & $0.41^{*}$ \\
Chl $a$ & $0.38^{*}$ & ns & ns & ns & ns \\
DOC & $0.48^{* *}$ & $0.38^{*}$ & ns & ns & ns \\
TDN & $-0.66^{* * *}$ & $-0.86^{* * *}$ & $-0.56^{* * *}$ & $0.65^{* * *}$ & $\mathrm{~ns}$ \\
TDP & ns & $0.42^{*}$ & ns & ns & ns \\
Nitrate & $-0.64^{* * *}$ & $-0.72^{* * *}$ & $-0.73^{* * *}$ & ns & ns \\
\hline
\end{tabular}

ships with bacterial activity parameters (bulk production and leucine-incorporating cells). Additionally, Betaproteobacteria were positively related to the TDP concentration, and the R-BT cluster to temperature. Actinobacteria were positively related only to the TDN concentration.

\section{DISCUSSION}

\section{Seasonal dynamics in bacterial community composition and single-cell activity}

Our results show that the bacterial community of the alpine lake studied, Gossenköllesee (GKS), responds to the main physical events (melting of the ice cover, mixis, stratification) and biological events (maxima in bacterial production, development of the deep chlorophyll maximum) in the lake, with clear changes in their activity and structure.

The heterotrophic bacterial assemblage of the GKS and other alpine lakes in the area is often co-dominated by Betaproteobacteria and Actinobacteria (Glöckner et al. 2000, Warnecke et al. 2005, Pérez \& Sommaruga 2006), which was also the case for our study. Although the predominance of Betaproteobacteria in freshwater systems has been described (Glöckner et al. 1999), recent evidence indicates that Actinobacteria is a prevailing group in numerous alpine lakes (Warnecke et al. 2005). Our study shows that both bacterial groups are subjected to marked seasonal changes and that their dominance alternates during the ice-free season.

In the present study, Actinobacteria was the most abundant group under the ice cover, in agreement with the report by Glöckner et al. (2000), but we also showed for the first time that this group profited most from the input of organic matter during ice-out. The significant positive relationship of Actinobacteria with TDN (but not with inorganic nitrogen forms), which reached its highest concentration under the ice and after the disappearance of the ice cover (Fig. 1D), suggests that these organisms were favored by the organic nitrogen compounds accumulated and produced in the ice cover. Recently, Hörtnagl et al. (2010) found that Actinobacteria in the neuston of the GKS were positively related to the TDN concentration in this layer, which acts as a collector for atmospheric deposition. The fact that the material present in the snow cover is mainly of microbial and atmospheric origin (Felip et al. 1999) suggests that Actinobacteria respond positively not only to soil-derived DOM (Pérez \& Sommaruga 2006) or algal-derived DOM (Stepanauskas et al. 2003, Nelson 2009), but to atmospheric sources of DOM as well. 
The relative abundance of Betaproteobacteria increased concomitantly with the concentrations of chl $a$ and DOC and a peak in bacterial production. The high abundances of Betaproteobacteria, in both absolute and relative terms, from August until the autumn overturn, seem to be a recurrent seasonal pattern in the GKS which was also observed in the study of Pernthaler et al. (1998) and its accompanying work (Glöckner et al. 2000). However, our study shows, additionally, that the increase in the abundance of Betaproteobacteria was caused by a single cluster of the Betaproteobacteria, the R-BT subgroup. The abundance of this subgroup was highest at the same time as the bulk bacterial production reached its maximum. This finding supports our previous results that showed that the R-BT subgroup is the most active bacterial group under different experimental manipulations (Pérez \& Sommaruga 2006, Pérez et al. 2010). In other freshwater systems, such as the meso-eutrophic Řimov Reservoir (Czech Republic), the R-BT subgroup is correlated to the fraction of cells with high nucleic acid content, which in turn, is tightly coupled to bacterial production (Šimek et al. 2005).

Water temperature was positively related to changes in the abundance of the R-BT cluster in the GKS. Members of this cluster are known to be fast-growing cells (Šimek et al. 2006), and because growth rate is usually positively affected by temperature, one hypothesis is that, during warmer periods, R-BT bacteria overgrow other members of the Betaproteobacteria. In a cold and oligotrophic lake such as the GKS, with a relatively short 'warm' season, this strategy might be advantageous. Although a positive relationship between phytoplankton dynamics (particularly cryptophytes) and the presence of the R-BT subgroup has been found in the Řimov Reservoir (Šimek et al. 2008), we could not find any significant relationship between this subgroup and the chl a concentration. However, our previous work showed that the R-BT subgroup was greatly stimulated by the addition of organic matter derived from algae (Pérez \& Sommaruga 2006).

Our study shows a clear temporal and vertical separation of the dominant bacterial groups in the GKS, as suggested by Glöckner et al. (2000), that translates into a highly significant negative relationship ( $\mathrm{r}=$ $-0.48, \mathrm{p}<0.01)$. As described before, Actinobacteria dominated the community structure under the ice cover and immediately after ice-out, indicating a preference for low temperatures and presumably less labile DOM, whereas Betaproteobacteria were more successful during the summer stratification using the autochthonously produced DOM. Further, we observed not only a temporal, but also a vertical, separation of these 2 groups in summer. In July, for example, Betaproteobacteria were more abundant at the surface of the lake, whereas Actinobacteria dominated in the deeper zone. Most likely, temperature influenced the vertical segregation of these 2 groups during the summer stratification. Another non-exclusive explanation for this vertical pattern might be the vertical distribution of heterotrophic flagellates in the GKS. Wille et al. (1999) found higher abundances of heterotrophic flagellates at the bottom of the lake $(8 \mathrm{~m})$ during the summer than at the surface. This is in agreement with reports indicating that Actinobacteria are favored in the presence of grazers due to their small cell size (Pernthaler et al. 2001, Jezbera et al. 2005). In contrast, members of Betaproteobacteria are known to be very sensitive to predation (Pernthaler et al. 2001). In particular, members of the R-BT subgroup, although fast-growing, are also very vulnerable to bacterivory (Šimek et al. 2005).

Cytophaga-like bacteria were the third most abundant group during our study, and they had high relative abundances after the ice-break and the subsequent thermal mixing - in agreement with Battin et al. (2001), who related their abundance to inputs of allochthonous organic material in a glacial stream. In addition, their relative abundance was positively related to bacterial production, as found by others (Eiler \& Bertilsson 2007), but not to the single-cell leucine incorporation (Table 1). This suggests that Cytophaga-like bacteria were favored by inputs of organic matter that drove both bacterial production bursts, but that they are not specialized in the uptake of monomers such as leucine (Cottrell \& Kirchman 2000). These authors associated Cytophaga-like bacteria with the degradation and uptake of highmolecular-weight DOM.

Alphaproteobacteria, although not very abundant, were consistently present during the whole study period and were positively related to concentrations of chl $a$ and DOC (Table 1). The increase in their relative abundance in our study, when chl a reached its highest value, suggests that limnetic Alphaproteobacteria might profit from actively growing phytoplankton as observed for their oceanic counterparts (Teira et al. 2008).

\section{Contribution of the dominant bacterial groups to community structure and leucine incorporation}

Although bacterial abundance was initially dominated by Actinobacteria, leucine incorporation at the single-cell level was driven mainly by Betaproteobacteria during the whole ice-free season. Independently from their relative abundance, Betaproteobacteria generally comprised the highest number of leucinepositive cells (Fig. 3), in agreement with the findings of Hornák et al. (2010). This was reflected by a highly 
significant positive relationship between Betaproteobacteria and the relative abundance of leucineincorporating cells, but not between the latter and Actinobacteria. We also observed a remarkable correlation ( $\mathrm{r}=0.81, \mathrm{p}<0.001)$ between the relative abundance of active Betaproteobacteria and that of the RBT subgroup. Only few recent studies (Hornák et al. 2006, 2010, Salcher et al. 2010) have assessed the contribution of particular freshwater bacterial groups to bacterial production, but in agreement with a study in the Ǩimov Reservoir (Hornák et al. 2006), Betaproteobacteria - and particularly their R-BT subgroup were found to drive the activity of the bacterial community. Although freshwater Actinobacteria are known to be an active component of the bacterial community (Warnecke et al. 2005, Pérez \& Sommaruga 2006), able to incorporate leucine in a wide range of freshwater systems (Buck et al. 2009, Hornák et al. 2010, Pérez et al. 2010), a positive relationship between this group and bacterial production has, to our knowledge, not been reported. The recent work of Salcher et al. (2010) showed that Actinobacteria in an oligomesotrophic lake have a preference for amino acids other than leucine, which could explain their proportionally low contribution to single-cell activity assessed with this amino acid. However, our preliminary data indicate that, at least in the late ice-free season (August and September), similar proportions of Actinobacteria incorporated leucine and an amino acid mixture in the GKS (M. T. Pérez unpubl. data).

\section{Concluding remarks}

Even at the large taxonomic resolution level used in this study, we detected changes in the dominance of the main bacterial groups that were associated with crucial biological and physical events in the lake. Actinobacteria dominated during the colder period under ice and immediately after the ice-out, profiting together with the Cytophaga-like bacteria - from the input of allochthonous material accompanying the iceout, whereas Betaproteobacteria, and particularly its R-BT subgroup, increased in importance during the summer stratification. Interestingly, the dominance of a certain group in terms of abundance did not imply that it was also responsible for driving the production of the bacterial assemblage, as shown for Actinobacteria. On the contrary, the contribution of Betaproteobacteria to total leucine-incorporating cells was always higher than expected by its relative abundance. This underlines the importance of assessing concomitantly both the structure and the single-cell activity of the bacterial community to understand the functioning of a particular ecosystem.
Acknowledgements. We thank J. Franzoi and W. Müller for nutrients and DOC analysis, and M. Summerer for kindly providing the chlorophyll a data. This work was supported by the Austrian Science Fund (FWF) through grants M788-B06 to M.T.P. and P19245-B03 to R.S.

\section{LITERATURE CITED}

Alonso-Sáez L, Gasol JM (2007) Seasonal variations in the contribution of different bacterial groups to the uptake of low-molecular-weight compounds in the northwestern Mediterranean coastal waters. Appl Environ Microbiol 73: 3528-3535

Amann RI, Ludwig W, Schleifer KH (1995) Phylogenetic identification and in situ detection of individual microbial cells without cultivation. Microbiol Rev 59:143-169

Battin TJ, Wille A, Sattler B, Psenner R (2001) Phylogenetic and functional heterogeneity of sediment biofilms along environmental gradients in a glacial stream. Appl Environ Microbiol 67:799-807

Buck U, Grossart HP, Amann R, Pernthaler J (2009) Substrate incorporation patterns of bacterioplankton populations in stratified and mixed waters of a humic lake. Environ Microbiol 11:1854-1865

> Cottrell MT, Kirchman D (2000) Natural assemblages of marine proteobacteria and members of the Cytophaga-Flavobacter cluster consuming low- and high-molecular-weight dissolved organic matter. Appl Environ Microbiol 66:1692-1697

Cottrell MT, Kirchman D (2003) Contribution of major bacterial groups to bacterial biomass production (thymidine and leucine incorporation) in the Delaware estuary. Limnol Oceanogr 48:168-178

> Daims H, Bruhl R, Amann R, Schleifer KH, Wagner M (1999) The domain-specific probe EUB338 is insufficient for the detection of all Bacteria: development and evaluation of a more comprehensive probe set. Syst Appl Microbiol 22:434-444

$>$ Eiler A, Bertilsson S (2007) Flavobacteria blooms in four eutrophic lakes: linking population dynamics of freshwater bacterioplankton to resource availability. Appl Environ Microbiol 73:3511-3518

Felip M, Camarero L, Catalan J (1999) Temporal changes of microbial assemblages in the ice and snow cover of a high mountain lake. Limnol Oceanogr 44:973-987

Glöckner FO, Amann R, Alfreider A, Pernthaler J, Psenner R, Trebesius K, Schleifer KH (1996) An in situ hybridization protocol for detection and identification of planktonic bacteria. Syst Appl Microbiol 19:403-406

> Glöckner FO, Fuchs BM, Amann R (1999) Bacterioplankton compositions of lakes and oceans: first comparison based on fluorescence in situ hybridization. Appl Environ Microbiol 65:3721-3726

Glöckner FO, ZaichIkov E, Belkova N, Denissova L, Pernthaler J, Pernthaler A, Amann R (2000) Comparative 16S rRNA analysis of lake bacterioplankton reveals globally distributed phylogenetic clusters including an abundant group of Actinobacteria. Appl Environ Microbiol 66:5053-5065

Hornák K, Jezbera J, Nedoma J, Gasol JM, Šimek K (2006) Effects of resource availability and bacterivory on leucine incorporation in different groups of freshwater bacterioplankton, assessed using microautoradiography. Aquat Microb Ecol 45:277-289

> Hornák K, Jezbera J, Šimek K (2010) Bacterial single-cell activities along the nutrient availability gradient in a canyon-shaped reservoir: a seasonal study. Aquat Microb Ecol 60:215-225

> Hörtnagl P, Pérez MT, Sommaruga R (2010) The bacterial 
community composition of the surface microlayer in a high mountain lake. FEMS Microbiol Ecol 73:458-467

Jezbera J, Hornák K, Šimek K (2005) Food selection by bacterivorous protists: insight from the analysis of the food vacuole content by means of fluorescence in situ hybridization. FEMS Microbiol Ecol 52:351-363

> Lee N, Nielsen PH, Andreasen KH, Juretschko S, Nielsen JL, Schleifer KH, Wagner M (1999) Combination of fluorescent in situ hybridization and microautoradiography-a new tool for structure-function analyses in mircrobial ecology. Appl Environ Microbiol 65:1289-1297

> Loreau M, Naeem S, Inchausti P, Bengtsson J and others (2001) Biodiversity and ecosystem functioning: current knowledge and future challenges. Science 294:804-808

Lorenzen CJ (1967) Determination of chlorophyll and phaeopigments: spectrophotometric equations. Limnol Oceanogr 12:343-346

Manz W, Amann R, Ludwig W, Wagner M, Schleifer KH (1992) Phylogenetic oligodeoxynucleotide probes for the major subclasses of Proteobacteria: problems and solutions. Syst Appl Microbiol 15:593-600

Manz W, Amann R, Ludwig W, Vancanneyt M, Schleifer KH (1996) Application of a suite of 16S rRNA-specific oligonucleotide probes designed to investigate bacteria of the phylum Cytophaga-Flavobacter-Bacteroides in the natural environment. Microbiology 142:1097-1106

Neef A (1997) Anwendung der in situ Einzelzell-Identifizierung von Bakterien zur Populationsanalyse in komplexen mikrobiellen Biozönosen. PhD thesis, Technical University of Munich

> Nelson CE (2009) Phenology of high-elevation pelagic bacteria: the roles of metereologic variability, catchment inputs and thermal stratification in structuring communities. ISME J 3:13-30

Ouverney CC, Fuhrman JA (1999) Combined microautoradiography-16S rRNA probe technique for determination of radioisotope uptake by specific microbial cell types in situ. Appl Environ Microbiol 65:1746-1752

Pechlaner R (1971) Factors that control the production rate and biomass of phytoplankton in high-mountain lakes. Mitt Int Ver Limnol 19:125-145

Pérez MT, Sommaruga R (2006) Differential effect of algaland soil-derived dissolved organic matter on alpine lake bacterial community composition and activity. Limnol Oceanogr 51:2527-2537

> Pérez MT, Hörtnagl P, Sommaruga R (2010) Contrasting ability to take up leucine and thymidine among freshwater bacterial groups: implications for bacterial production measurements. Environ Microbiol 12:74-82

Pernthaler A, Pernthaler J, Amann R (2002) Fluorescence in situ hybridization and catalyzed reporter deposition for the identification of marine bacteria. Appl Environ Microbiol 68:3094-3101

> Pernthaler J, Glöckner FO, Unterholzner S, Alfreider A, Psenner R, Amann R (1998) Seasonal community and population dynamics of pelagic bacteria and archaea in a high mountain lake. Appl Environ Microbiol 64:4299-4306

Pernthaler J, Posch T, Šimek K, Vrba J and others (2001) Predator-specific enrichment of Actinobacteria from a cosmopolitan freshwater clade in mixed continuous culture. Appl Environ Microbiol 67:2145-2155

Roller C, Wagner M, Amann R, Ludwig W, Schleifer KH (1994) In situ probing of gram-positive bacteria with high DNA G+C content using 23S rRNA-targeted oligonucleotides. Microbiology 140:2849-2858

Salcher MM, Pernthaler J, Posch T (2010) Spatiotemporal distribution and activity patterns of bacteria from three

Editorial responsibility: Karel Šimek,

České Budějovice, Czech Republic phylogenetic groups in an oligomesotrophic lake. Limnol Oceanogr 55:846-856

Schmid M, Ambühl H (1965) Die Bestimmung geringster Mengen von Gesamtphosphor im Wasser von Binnenseen. Schweiz Z Hydrol 27:184-192

> Sekar R, Pernthaler A, Pernthaler J, Warnecke F, Posch T, Amann R (2003) An improved method for quantification of freshwater Actinobacteria by fluorescence in situ hybridization. Appl Environ Microbiol 69:2928-2935

Šimek K, Pernthaler J, Weinbauer MG, Hornák K and others (2001) Changes in bacterial community composition and dynamics and viral mortality rates associated with enhanced flagellate grazing in a mesoeutrophic reservoir. Appl Environ Microbiol 67:2723-2733

Šimek K, Hornák K, Jezbera J, Masín M, Nedoma J, Gasol JM, Schauer M (2005) Influence of top-down and bottom-up manipulations on the R-BT065 subcluster of $\beta$-Proteobacteria, an abundant group in bacterioplankton of a freshwater reservoir. Appl Environ Microbiol 71:2381-2390

Šimek K, Hornák K, Jezbera J, Nedoma J and others (2006) Maximum growth rates and possible life strategies of different bacterioplankton groups in relation to phosphorus availability in a freshwater reservoir. Environ Microbiol 8: 1613-1624

Šimek K, Hornák K, Jezbera J, Nedoma J, Znachor P, Hejzlar J, Sed'a J (2008) Spatio-temporal patterns of bacterioplankton production and community composition related to phytoplankton composition and protistan bacterivory in a dam reservoir. Aquat Microb Ecol 51:249-262

Sommaruga R (2001) The role of solar UV radiation in the ecology of alpine lakes. J Photochem Photobiol B-Biol 62: $35-42$

Sommaruga R, Augustin G (2006) Seasonality in UV transparency of an alpine lake is associated to changes in phytoplankton biomass. Aquat Sci 68:129-141

Stepanauskas R, Moran MA, Bergamaschi BA, Hollibaugh JT (2003) Covariance of bacterioplankton composition and environmental variables in a temperate delta system. Aquat Microb Ecol 31:85-98

Tabor PS, Neihof RA (1982) Improved microautoradiographic method to determine individual microorganisms active in substrate uptake in natural waters. Appl Environ Microbiol 44:945-953

Taras MJ (ed) (1971) Standard methods for the examination of water and wastewater. American Public Health Association, New York, NY

Tartarotti B, Sommaruga R (2006) Seasonal and ontogenetic changes of mycosporine-like amino acids in planktonic organisms from an alpine lake. Limnol Oceanogr 51:1530-1541

Teira E, Gasol JM, Aranguren-Gassis M, Fernández A, González J, Lekunberri I, Alvarez-Salgado XA (2008) Linkages between bacterioplankton community composition, heterotrophic carbon cycling and environmental conditions in a highly dynamic coastal ecosystem. Environ Microbiol 10:906-917

Warnecke F, Sommaruga R, Sekar R, Hofer JS, Pernthaler J (2005) Abundances, identity and growth state of Actinobacteria in mountain lakes of different UV transparency. Appl Environ Microbiol 71:5551-5559

Wille A, Sonntag B, Sattler B, Psenner R (1999) Abundance, biomass and size structure of the microbial assemblage in the high mountain lake Gossenköllesee (Tyrol, Austria) during the ice-free period. J Limnol 58:117-126

> Zhang Y, Jiao N, Cottrell MT, Kirchman D (2006) Contribution of major bacterial groups to bacterial biomass production along a salinity gradient in the south China Sea. Aquat Microb Ecol 43:233-241 